\title{
Changes in human sirtuin 6 gene promoter methylation during aging
}

\author{
KANIYE SAHIN, SIBEL YILMAZ and NERMIN GOZUKIRMIZI
}

Department of Molecular Biology and Genetics, Faculty of Science, Istanbul University, 34118 Vezneciler, Istanbul, Turkey

Received February 25, 2014; Accepted March 26, 2014

DOI: 10.3892/br.2014.266

\begin{abstract}
Aging is a natural process during which changes at the cellular level increase death risk by developing susceptibility to a variety of diseases. Sirtuins have been shown to regulate lifespan in various organisms by deacetylating a number of important transcription factors. Of the 7 identified mammalian sirtuins (SIRT1-7), SIRT6 depletion is associated with severe symptoms of premature aging. In this study, we investigated the association between human longevity and SIRT6 promoter methylation. Genomic DNA from blood samples of 55 individuals (34 females and 21 males) was examined to detect methylation levels by quantitative polymerase chain reaction analysis following bisulfite treatment. While the results indicated $43.21 \%$ methylation in the 9-19 age group, this ratio was found to be increased up to $65.63 \%$ in the $20-79$ age group and decreased to $52.15 \%$ in the 80-95 age group. Our results demonstrated that the SIRT6 gene is more active between 9-19 and 80-95 years compared to 20-79 years.
\end{abstract}

\section{Introduction}

Sirtuins have attracted significant interest in aging studies over the last decade. Sirtuins have been shown to regulate important biological pathways in bacteria, archaea and eukaryotes by possessing $\mathrm{NAD}^{+}$-dependent histone deacetylase, mono-ribosyltransferase and tumor suppressor activity and by regulating gene expression or DNA repair (1-4). Of the 7 human sirtuins identified, the human SIRT6 gene is located on the minus strand of chromosome $19 \mathrm{p} 13.3$ and is available in a single copy encoding a 355 -amino acid protein (39.1 kDa) (5). The SIRT6 protein localizes in the nucleus (6) and is required for DNA repair and maintenance of genomic stability in mammalian cells, integrating stress signaling to activate the DNA repair machinery in response to oxidative

Correspondence to: Professor Nermin Gozukirmizi, Department of Molecular Biology and Genetics, Faculty of Science, Istanbul University, 2 Sehzadebasi, Vezneciler-Istanbul 34118, Turkey

E-mail: nermin@istanbul.edu.tr

Key words: sirtuin 6, methylation, longevity, bisulfite, quantitative polymerase chain reaction stress $(7,8)$. Knockdown of SIRT6 in human cells renders them prone to chemically induced double-strand breaks $(2,9)$. SIRT6 deficiency in mice has been shown to lead to the development of an acute degenerative aging-like phenotype (10). Although studies on SIRT6 knockout mice reported a strong correlation between premature aging and the absence of the SIRT6 protein (10), the reports on the overexpression of sirtuin homologues on various model organisms have been controversial, from no effect (11) to expansion of lifespan only in male mice (12). Analyses at the mRNA and protein level revealed SIRT6 expression in the majority of mouse and human tissues, with particularly high protein levels in the thymus, skeletal muscle and brain $(13,14)$. However, there is no sufficient data on SIRT6 promoter methylation levels and their correlation with human longevity. To address this issue, we investigated the SIRT6 promoter methylation levels in 55 individuals of a wide age range by bisulfite-quantitative polymerase chain reaction (qPCR). The aim of this study was to elucidate the correlation between the percentage of SIRT6 promoter methylation and age and investigate whether it exhibits any association with longevity.

\section{Materials and methods}

Subjects and sample collection. This study included 55 individuals (34 females and 21 males), aged 9-95 years, divided into 8 age groups with 10 -year intervals, with the exception of the 1st (9-19) and the 8th groups (80-95 years). Blood samples were collected at the Istanbul University Medico-Social Center, Turkey, with the written consent of the individuals who completed a form indicating their background regarding gender, age, inherited diseases, cancer, exposure to chemical or radioactive agents, permanent use of medicines, smoking habits and presence in the family of individuals aged $>90$ years. Genomic DNA was extracted from the blood samples using the High Pure PCR Template Preparation kit (Roche Diagnostics GmbH, Mannheim, Germany).

The procedures followed were in accordance with the current ethical standards.

Primer selection. The promoter sequence for SIRT6 was extracted and combined from Transcriptional Regulatory Element Database by Cold Spring Harbor Laboratory, Eukaryotic Promoter Database by the Swiss Institute of Bioinformatics and Promoter Controls by SwitchGear 
Table I. Evaluation of the subjects.

\begin{tabular}{|c|c|c|c|c|c|c|c|}
\hline Group no. & Subject no. & Gender & $\begin{array}{c}\text { SIRT6 promoter } \\
\text { methylation } \\
(\%)\end{array}$ & $\begin{array}{c}\text { Age } \\
\text { (years) }\end{array}$ & $\begin{array}{c}\text { Permanent } \\
\text { medical treatment } \\
+\end{array}$ & $\begin{array}{l}\text { Smoking } \\
\text { habit } \\
+\end{array}$ & $\begin{array}{c}\text { Extended longevity } \\
\text { in the family } \\
+\end{array}$ \\
\hline \multirow[t]{7}{*}{1} & $1-1$ & Male & 66.74 & 9 & & & $X$ \\
\hline & $1-2$ & Female & 65.25 & 9 & & & \\
\hline & $2-1$ & Male & 37.18 & 11 & & & $X$ \\
\hline & $2-2$ & Female & 46.22 & 15 & & & $\mathrm{X}$ \\
\hline & $2-3$ & Male & 15.63 & 15 & & & \\
\hline & $2-4$ & Female & 15.10 & 17 & $X$ & & $X$ \\
\hline & $2-5$ & Female & 56.34 & 19 & & & $X$ \\
\hline \multirow[t]{9}{*}{2} & $3-1$ & Male & 62.76 & 20 & & & \\
\hline & $3-2$ & Male & 53.97 & 24 & & & \\
\hline & $3-3$ & Female & 78.08 & 22 & & & $X$ \\
\hline & $3-4$ & Male & 67.40 & 24 & & $X$ & $\mathrm{X}$ \\
\hline & $3-5$ & Female & 52.57 & 22 & $X$ & & \\
\hline & $3-6$ & Male & 59.40 & 23 & & $X$ & \\
\hline & $3-7$ & Female & 68.00 & 20 & & & $X$ \\
\hline & $3-8$ & Female & 63.75 & 24 & $\mathrm{X}$ & & \\
\hline & $3-9$ & Male & 63.39 & 24 & $X$ & & $X$ \\
\hline \multirow[t]{9}{*}{3} & $4-1$ & Male & 70.42 & 32 & & & $X$ \\
\hline & $4-2$ & Female & 59.46 & 32 & $X$ & & $X$ \\
\hline & $4-3$ & Male & 62.38 & 32 & & $X$ & \\
\hline & $4-4$ & Female & 67.02 & 32 & $X$ & $X$ & $X$ \\
\hline & $4-5$ & Male & 71.41 & 32 & $\mathrm{X}$ & & \\
\hline & $4-6$ & Male & 65.43 & 32 & & $X$ & $X$ \\
\hline & $4-7$ & Female & 65.13 & 33 & $X$ & & $X$ \\
\hline & $4-8$ & Female & 64.85 & 34 & $X$ & & \\
\hline & 4-9 & Female & 61.03 & 34 & & & \\
\hline \multirow[t]{7}{*}{4} & $5-1$ & Female & 45.98 & 47 & & & $X$ \\
\hline & $5-2$ & Female & 52.22 & 45 & & & $X$ \\
\hline & $5-3$ & Male & 65.78 & 44 & & & \\
\hline & $5-4$ & Female & 78.19 & 42 & $X$ & & \\
\hline & $5-5$ & Female & 69.98 & 45 & $X$ & & \\
\hline & $5-6$ & Female & 77.30 & 42 & & & \\
\hline & $5-7$ & Male & 73.96 & 41 & & $X$ & $X$ \\
\hline \multirow[t]{6}{*}{5} & $6-1$ & Female & 67.91 & 51 & & & $X$ \\
\hline & $6-2$ & Female & 59.96 & 51 & $X$ & & \\
\hline & $6-3$ & Female & 74.64 & 52 & $X$ & $X$ & \\
\hline & $6-4$ & Female & 68.55 & 52 & $X$ & $X$ & $X$ \\
\hline & $6-5$ & Male & 76.36 & 53 & $X$ & & \\
\hline & $6-6$ & Female & 68.26 & 59 & $X$ & & \\
\hline \multirow[t]{5}{*}{6} & $7-1$ & Female & 65.19 & 63 & $X$ & & \\
\hline & $7-2$ & Female & 75.60 & 65 & $X$ & & \\
\hline & $7-3$ & Male & 74.31 & 67 & $X$ & & \\
\hline & $7-4$ & Male & 72.99 & 65 & $X$ & & $X$ \\
\hline & $7-5$ & Female & 56.70 & 64 & $X$ & & $X$ \\
\hline \multirow[t]{5}{*}{7} & $8-1$ & Female & 64.05 & 71 & $X$ & & $X$ \\
\hline & $8-2$ & Female & 62.30 & 72 & $X$ & & \\
\hline & $8-3$ & Female & 60.05 & 73 & $X$ & & $X$ \\
\hline & $8-4$ & Female & 52.22 & 75 & $X$ & & \\
\hline & $8-5$ & Male & 65.51 & 75 & $X$ & & \\
\hline \multirow[t]{2}{*}{8} & $9-1$ & Male & 39.87 & 80 & $X$ & & \\
\hline & $9-2$ & Female & 31.51 & 83 & $\mathrm{X}$ & & $X$ \\
\hline
\end{tabular}


Table I. Continued.

\begin{tabular}{|c|c|c|c|c|c|c|c|}
\hline Group no. & Subject no. & Gender & $\begin{array}{l}\text { SIRT6 promoter } \\
\text { nethylation } \\
(\%)\end{array}$ & $\begin{array}{l}\text { Age } \\
\text { (years) }\end{array}$ & $\begin{array}{c}\text { Permanent } \\
\text { medical treatment } \\
+\end{array}$ & $\begin{array}{c}\text { Smoking } \\
\text { habit } \\
+\end{array}$ & $\begin{array}{c}\text { Extended longevity } \\
\text { in the family } \\
+\end{array}$ \\
\hline & $9-3$ & Female & 39.11 & 83 & X & & \\
\hline & $9-4$ & Male & 35.17 & 88 & $X$ & & $X$ \\
\hline & $9-5$ & Female & 86.39 & 88 & & & $\mathrm{X}$ \\
\hline & $10-1$ & Female & 66.25 & 91 & $\mathrm{X}$ & & $\mathrm{X}$ \\
\hline & $10-2$ & Male & 66.74 & 95 & $\mathrm{X}$ & & $\mathrm{X}$ \\
\hline
\end{tabular}

SIRT6, sirtuin 6 gene.

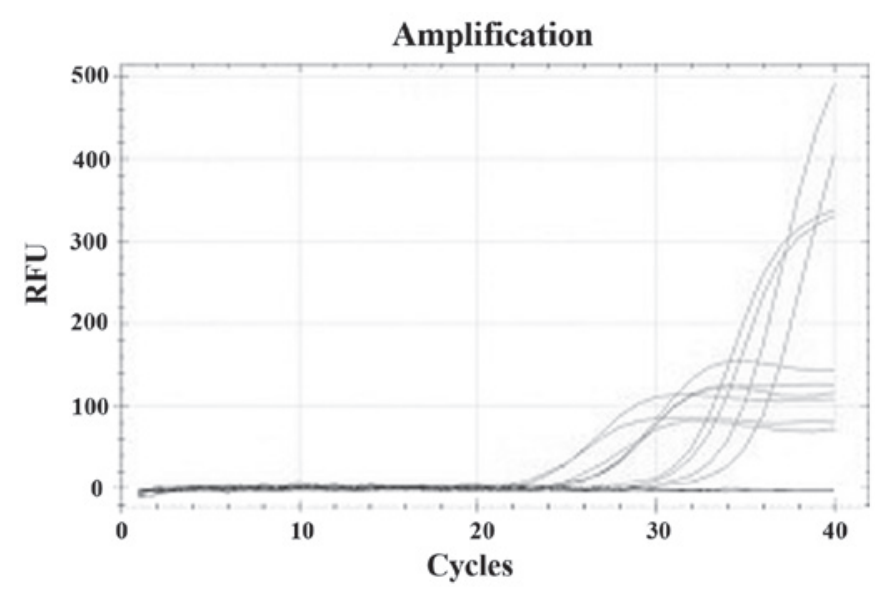

Figure 1. Amplification curve of the standards. Methylated standards (100, $80,60,20$ and $10 \%$ ) were used to assess the methylation levels of the samples. RFU, relative fluorescence units.

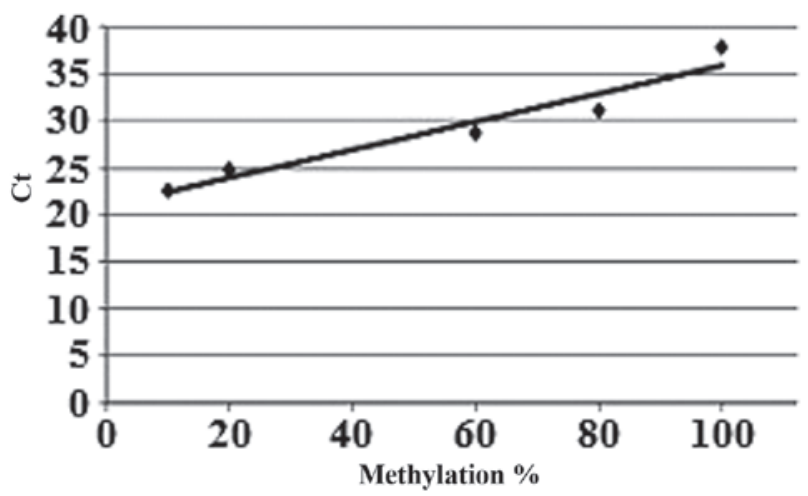

Figure 2. Standard methylation curve. The methylation curve was established by the standards $\left(R^{2}=0.9335\right)$.

Genomics. The $\mathrm{CpG}$ islands were identified with the $\mathrm{CpG}$ Island Searcher (GC=66.2\%; http://cpgislands.usc.edu). The primers were designed specifically for bisulfite-converted DNA with the MethPrimer (v1.1 beta) program (http://www. urogene.org/cgi-bin/methprimer/methprimer.cgi). The primer sequences were 5'-TTAATAAGGGAAATTTTATTGTTTT-3' for the forward primer and 5'-CTAACCTCAATACCC CCTAATATTC-3' for the reverse primer targeting a 212-bp region on the SIRT6 promoter.

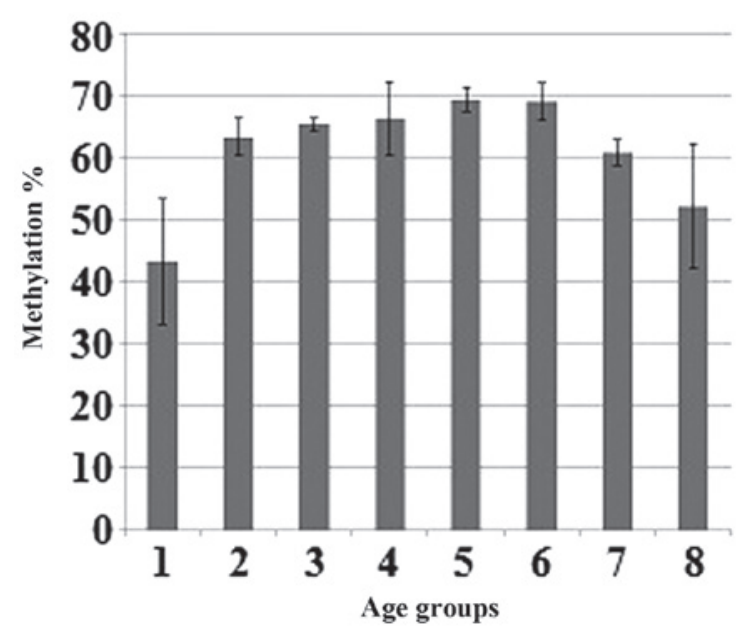

Figure 3. Average methylation percentage in different age groups. Age group $1,9-19 ; 2,20-29 ; 3,30-39 ; 4,40-49 ; 5,50-59 ; 6,60-69 ; 7,70-79$; and $8,80-95$ years.

Bisulfite- $q P C R$. A total of $500 \mathrm{ng}$ of the extracted genomic DNAs were bisulfite-converted by the EZ DNA Methylation ${ }^{\text {TM }}$ kit (D5002; Zymo Research, Irvine, CA, USA) according to the manufacturer's recommendations. The converted DNA samples were dissolved in $15 \mu \mathrm{l}$ elution buffer. The concentration of the eluted DNA was measured by NanoDrop (2000c; Thermo Scientific, Waltham, MA, USA) as RNA due to the single-stranded nature and uracil content of the bisulfite-converted DNA. The extracted DNAs were diluted to a concentration of $20 \mathrm{ng} / \mu \mathrm{l}$. The specificity of the primers was confirmed by agarose gel electrophoresis following bisulfite-PCR using $20 \mathrm{ng}$ sample DNA. To assess the methylation level of the region of interest, fully methylated (D5015; Zymo Research) and demethylated (EpiTect ${ }^{\circledR}$ Control DNA, 59665; Qiagen, Hilden, Germany) bisulfite-converted control DNAs were mixed accordingly to obtain 100, 80, 60, 20 and $10 \%$ methylated standards. A total of $10 \mathrm{ng}$ of standards and sample DNAs were used for qPCR (CFX96; Bio-Rad, Hercules, CA, USA) along with $0.5 \mu \mathrm{M}$ primers, $0.25 \mathrm{mM}$ dNTP, $1 \mathrm{X}$ SYBR-Green I (Bioline, Taunton, MA, USA) and 0.5 unit of ZymoTaq $^{\mathrm{TM}}$ DNA polymerase (E2002; Zymo Research) in a total volume of $10 \mu 1$. The PCR conditions were as follows: initial denaturation at $95^{\circ} \mathrm{C}$ for $10 \mathrm{~min}$, followed by 40 cycles of denaturation at $95^{\circ} \mathrm{C}$ for $30 \mathrm{sec}$, annealing at $57^{\circ} \mathrm{C}$ for $30 \mathrm{sec}$ 
and extension with a plate reading step at $72^{\circ} \mathrm{C}$ for $1 \mathrm{~min}$ followed by a melting curve analysis step from $65^{\circ} \mathrm{C}$ to $95^{\circ} \mathrm{C}$ by $0.5^{\circ} \mathrm{C}$ increments for $5 \mathrm{sec}$. All the samples were examined in double replicates and the standard DNAs in triple replicates. The $C_{t}$ values for the standard DNAs were used to generate a standard curve. The methylation levels of all the subjects were calculated according to the standard curve formula. The average methylation status of the age groups and standard deviations were calculated.

Statistical analysis. The significance levels of the probable association of SIRT6 promoter methylation rates with gender, smoking and longevity were calculated using non-parametric Kruskal-Wallis one-way analysis of variance. $\mathrm{P}<0.05$ was considered to indicate a statistically significant difference.

\section{Results}

Bisulfite- $q P C R$. The concentrations of the extracted bisulfite-converted DNAs were measured to be 23.5-39.1 ng/ $\mu \mathrm{l}$ and were diluted to $20 \mathrm{ng} / \mu \mathrm{l}$. Following qPCR analysis, a standard curve was generated with the mean $C_{t}$ values of the standards (Figs. 1 and 2). The SIRT6 promoter methylation levels of the subjects were calculated using their mean $\mathrm{C}_{\mathrm{t}}$ values according to the standard curve formula: $y=0.1493 x+20.966$

The methylation levels and information on the subjects are presented in Table I.

The average methylation percentages in different age groups were calculated. The methylation of the SIRT6 promoter was found to be $43.21 \%$ in the $9-19$ age group, an average of $65.63 \%$ in the $20-79$ age group and $52.15 \%$ in the 80-95 age group (Fig. 3).

Statistical analysis. The Kruskal-Wallis test confirmed that the methylation differences between at least two age groups were significant $(\mathrm{P}=0.011)$. However, we were unable to identify a significant correlation between methylation status and gender $(\mathrm{P}=0.806)$, smoking $(\mathrm{P}=0.180)$, family history of cancer $(\mathrm{P}=0.504)$, exposure to chemical or radioactive agents $(\mathrm{P}=0.085)$, or extended longevity in the family $(\mathrm{P}=0.556)$.

\section{Discussion}

In this study, we determined the promoter methylation status of the human SIRT6 gene in lymphocytes of 55 subjects aged 9-95 years. Our data indicated that the promoter was highly methylated between 20 and 79 years. The regulatory association of methylation of $\mathrm{CpG}$ islands in the repression of gene expression was previously established (15). However, there was no significant correlation with longevity, gender, permanent medical treatment or smoking observed in our study. These results are consistent with those reported by Michishita et al (16), who demonstrated that the overexpression of SIRT6 in fibroblasts or epithelial cells was not associated with a lifespan extension compared to normal cells.

There are currently no available data on the methylation levels of the human SIRT6 promoter. However, Ren et al (17) demonstrated that SIRT6 mRNA levels in porcine brain decreased with age, which is an indicator of a possible increase in promoter methylation. By contrast, SIRT6 protein levels were found to be increased during aging in diabetic mice (18) and following exercise in young and older mice (19). There is also accumulating evidence that SIRT6 is regulated in a circadian fashion. It was proven that $\mathrm{NAD}^{+}$levels and SIRT1 activity change according to a circadian rhythm $(20,21)$. SIRT6 is a NAD ${ }^{+}$-dependent enzyme and is also positively regulated by SIRT1 (22). Therefore, it is possible that SIRT6 is also regulated in a circadian manner. Marquardt et al (23) demonstrated that changing the SIRT6 expression in mice also changed the expression of certain genes related to the circadian rhythm.

SIRT6 is a chromatin-associated protein expressed in the majority of tissues. To gain insight into SIRT6 function, a characterization of the subcellular and tissue distribution patterns of its expression is required. Apart from age, SIRT6 expression or activity may change during the day, before and after meals or before and after exercise $(19,24,25)$. In summary, we demonstrated that promoter methylation of human SIRT6 is detectable by bisulfite-qPCR, but there was no correlation with longevity. Further research and clinical studies are required to fully elucidate the mechanisms underlying the process of aging.

\section{Acknowledgements}

This study was supported by the Istanbul University Department of Scientific Research Project (grant no. 21953).

\section{References}

1. Kawahara TL, Michishita E, Adler AS, et al: SIRT6 links histone $\mathrm{H} 3$ lysine 9 deacetylation to NF-kappaB-dependent gene expression and organismal life span. Cell 136: 62-74, 2009.

2. McCord RA, Michishita E, Hong T, et al: SIRT6 stabilizes DNA-dependent protein kinase at chromatin for DNA double-strand break repair. Aging (Albany NY) 1: 109-121, 2009.

3. Michishita E, McCord RA, Berber E, et al: SIRT6 is a histone H3 lysine 9 deacetylase that modulates telomeric chromatin. Nature 452: 492-496, 2008.

4. Sebastian C, Zwaans BM, Silberman DM, et al: The histone deacetylase SIRT6 is a tumor suppressor that controls cancer metabolism. Cell 151: 1185-1199, 2012.

5. Mahlknecht U,Ho AD and Voelter-Mahlknecht S: Chromosomal organization and fluorescence in situ hybridization of the human sirtuin 6 gene. Int J Oncol 28: 447-456, 2006.

6. Tennen RI, Berber E and Chua KF: Functional dissection of SIRT6: identification of domains that regulate histone deacetylase activity and chromatin localization. Mech Ageing Dev 131: 185-192, 2010

7. Mao Z, Hine C, Tian X, et al: SIRT6 promotes DNA repair under stress by activating PARP1. Science 332: 1443-1446, 2011.

8. Cardus A, Uryga AK, Walters G and Erusalimsky JD: SIRT6 protects human endothelial cells from DNA damage, telomere dysfunction, and senescence. Cardiovasc Res 97: 571-579, 2013.

9. Kaidi A, Weinert BT, Choudhary C and Jackson SP: Human SIRT6 promotes DNA end resection through CtIP deacetylation. Science 329: 1348-1353, 2010.

10. Mostoslavsky R, Chua KF, Lombard DB, et al: Genomic instability and aging-like phenotype in the absence of mammalian SIRT6. Cell 124: 315-329, 2006.

11. Burnett C, Valentini S, Cabreiro F, et al: Absence of effects of Sir2 overexpression on lifespan in C. elegans and Drosophila. Nature 477: 482-485, 2011.

12. Kanfi Y, Naiman S, Amir G, et al: The sirtuin SIRT6 regulates lifespan in male mice. Nature 483: 218-221, 2012.

13. Moschen AR, Wieser V, Gerner RR, et al: Adipose tissue and liver expression of SIRT1, 3, and 6 increase after extensive weight loss in morbid obesity. J Hepatol 59: 1315-1322, 2013.

14. Lee OH, Kim J, Kim JM, et al: Decreased expression of sirtuin 6 is associated with release of high mobility group box-1 after cerebral ischemia. Biochem Biophys Res Commun 438: 388-394, 2013. 
15. Kundu TK and Rao MR: CpG islands in chromatin organization and gene expression. J Biochem 125: 217-222, 1999.

16. Michishita E, Park JY, Burneskis JM, Barrett JC and Horikawa I: Evolutionarily conserved and nonconserved cellular localizations and functions of human SIRT proteins. Mol Biol Cell 16: 4623-4635, 2005.

17. Ren Y, Shan TZ, Zhu LN, Wu T, Guo J and Wang YZ: Effect of breed on the expression of sirtuins (Sirt1-7) and antioxidant capacity in porcine brain. Animal 7: 1994-1998, 2013.

18. Ghiraldini FG, Crispim AC and Mello ML: Effects of hyperglycemia and aging on nuclear sirtuins and DNA damage of mouse hepatocytes. Mol Biol Cell 24: 2467-2476, 2013.

19. Koltai E, Szabo Z, Atalay M, et al: Exercise alters SIRT1, SIRT6, NAD and NAMPT levels in skeletal muscle of aged rats. Mech Ageing Dev 131: 21-28, 2010.

20. Nakahata Y, Sahar S, Astarita G, Kaluzova M and Sassone-Corsi P: Circadian control of the NAD ${ }^{+}$salvage pathway by CLOCK-SIRT1. Science 324: 654-657, 2009.
21. Bellet MM and Sassone-Corsi P: Mammalian circadian clock and metabolism - the epigenetic link. J Cell Sci 123: 3837-3848, 2010.

22. Kim HS, Xiao C, Wang RH, et al: Hepatic-specific disruption of SIRT6 in mice results in fatty liver formation due to enhanced glycolysis and triglyceride synthesis. Cell Metab 12: 224-236, 2010.

23. Marquardt JU, Fischer K, Baus K, et al: Sirtuin-6-dependent genetic and epigenetic alterations are associated with poor clinical outcome in hepatocellular carcinoma patients. Hepatology 58: 1054-1064, 2013.

24. Ban N, Ozawa Y, Inaba T, Miyake S, Watanabe M, Shinmura K and Tsubota $\mathrm{K}$ : Light-dark condition regulates sirtuin mRNA levels in the retina. Exp Gerontol 48: 1212-1217, 2013.

25. Kanfi Y, Shalman R, Peshti V, et al: Regulation of SIRT6 protein levels by nutrient availability. FEBS Lett 582: 543-548, 2008. 